\title{
Effective composting of oil palm industrial waste by filamentous fungi: A review.
}

\begin{abstract}
Palm oil production is a major agricultural industry in Malaysia, in which palm oil mill effluent (POME) and oil palm empty fruit bunch (EFB) are considered as major waste products from the palm oil industry. These waste products create an environmental hazard and entail high disposal costs every year. Composting is a biologically based process which is practiced to stabilize the organic matter for soil amendment (producing compost) and to protect the environment from the detrimental effects of these waste products. This study reviews the composting process of EFB and POME as a single substrate and/or their mixture by using potential filamentous fungi that are especially lignocellulolytic and antibiotic (in a matured stage) in nature within several effective parameters, for example, $\mathrm{C} / \mathrm{N}$ ratio, moisture content, $\mathrm{pH}$, temperature, etc. Several studies record the mature composting process as being 60 days. In most cases, temperature and moisture content was maintained up to $70{ }^{\circ} \mathrm{C}$ and $60-75 \%$, respectively. In addition, this study reviews EFB and POME with their constituents for an efficient composting process.
\end{abstract}

Keyword: Composting; Agro-industrial wastes; Empty fruit bunches; Palm oil mill effluent; Filamentous fungi; Review. 